\title{
Coronavirus and Immigration Detention in Europe: The Short Summer of Abolitionism?
}

\author{
José A. Brandariz * and Cristina Fernández-Bessa
}

Citation: Brandariz, José A., and Cristina Fernández-Bessa. 2021.

Coronavirus and Immigration

Detention in Europe: The Short Summer of Abolitionism? Social Sciences 10: 226. https://doi.org/ $10.3390 /$ socsci10060226

Academic Editors: Robert Koulish and Nigel Parton

Received: 15 May 2021

Accepted: 10 June 2021

Published: 12 June 2021

Publisher's Note: MDPI stays neutral with regard to jurisdictional claims in published maps and institutional affiliations.

Copyright: (C) 2021 by the authors. Licensee MDPI, Basel, Switzerland. This article is an open access article distributed under the terms and conditions of the Creative Commons Attribution (CC BY) license (https:// creativecommons.org/licenses/by/ $4.0 /)$.
ECRIM, Law School, University of A Coruña, Campus de Elviña, s/n, 15071 A Coruña, Spain; c.fernandezb@udc.es

* Correspondence: jose.angel.brandariz@udc.es

Keywords: coronavirus; immigration detention; migration enforcement; detention abolition

\section{Introduction}

The coronavirus pandemic, which started in early 2020, has deeply shaken the foundations of our social life, turning upside down every dimension of our world. Specifically, the COVID-19 pandemic has had a seismic impact on human mobility, since international-and, in many cases, even local - travel was immediately singled out as a critical risk factor of coronavirus infection. Consequently, public health policies aimed at curbing the pandemic have fuelled a wide variety of re-bordering processes (Genschel and Jachtenfuchs 2021; Wille and Kanesu 2020). In fact, more than 140 countries had imposed border crossing restrictions in April 2020, in the framework of the first phase of the public health crisis (Connor 2020). ${ }^{1}$ In various regions, these were unprecedented measures. Schengen member states reintroduced border control at internal borders 122 times from 2006 to 2019, whilst these controls were reinstated 170 times from just March 2020 to April 2021, in all but seven cases for coronavirus-related reasons (source: European Commission 2021). Re-bordering processes, though, have gone far beyond measures aimed at re-erecting physical barriers. In many aspects, anti-coronavirus strategies have boosted chauvinist agendas, hampering previous international cooperation efforts. This shortcoming was especially evident in the case of the European Union (EU), for EU institutions largely failed to provide the much-needed leadership in the continental management of the crisis (Hall et al. 2020; Kluth 2021).

Given the far-reaching impact of anti-covid policies on human mobility, it is unsurprising that they have profoundly affected migration management practices. Travel bans and public health measures have significantly shifted a variety of border arrangements, including visa and legal residence policies, asylum practices and deportation procedures. Immigration detention has ranked high in this regard. As confinement institutions were reasonably tagged as critical hot spots for coronavirus infection since the onset of the crisis, 
they made up a major concern for national and international public health authorities (WHO 2020). This concern was focused on prisons but also on other facilities characterised by freedom of movement restrictions in which physical distancing measures are not feasible, such as asylum reception centres and migration detention facilities.

The COVID-19 crisis has resulted in various changes in the field of immigration detention. It has altered detention conditions in a variety of ways, from curtailing detention places and implementing distancing protocols to further isolating detainees by suspending visitation procedures (European Commission 2020a). In addition, the pandemic has called into question the role and goals and migration detention policies, in a period in which deportation efforts have been significantly eroded by the coronavirus turmoil. In this scenario, public health concerns have taken the lead over other public policy priorities, resulting in significant contingents of immigration detainees being released in many jurisdictions.

This paper explores the impact of the coronavirus pandemic on immigration detention by essentially spotlighting these exceptional release practices. A good reason to embrace this viewpoint is that those practices—at least during a "short summer" — might operate as a window of opportunity to reflect on detention abolition, that is, as a rare opportunity to envision new migration enforcement arrangements giving preference to alternatives to detention over confinement measures (Roman 2020; Weber 2020; see also MajkowskaTomkin 2020). Having said that, neither immigration detention practices have a global reach (Brandariz 2021) nor recent release policies were implemented globally (Chew et al. 2020; Dehm 2020). Consequently, European countries make up a suitable (continental) case to examine how and to what extent the sanitary crisis has contributed to change immigration detention. More precisely, Spain was the only global north country that closed down all immigration detention facilities for some time in mid-2020. Therefore, Spain may be an appropriate point of reference to reflect on immigration enforcement goals and alternatives to detention in a post-pandemic world.

No wide-encompassing, comparative and detailed database on immigration detention changes implemented in the framework of the coronavirus has been released yet. Consequently, this paper largely draws on the information supplied by a wide number of reports published by NGOs and watchdog institutions, ${ }^{2}$ as well as on media articles and some official law enforcement statistics. Building on these unsystematic data, the paper proceeds as follows. Initially, it presents the immigration detention changes implemented across Europe, and specifically in Spain to prevent coronavirus infections. Subsequently, the paper explores the forces and conditions contributing to the detention population decline witnessed in many European jurisdictions in mid-2020, as well as the strengths and weaknesses of those unprecedented policies for a detention abolition agenda. Drawing on this reflection, the paper outlines some conclusions on what can be learned from an exceptional time that we metaphorically call the "brief summer of abolitionism" in the field of immigration detention.

\section{Public Health Policies and the Immigration Detention Decline}

Immediately after the World Health Organization (WHO) qualified the coronavirus crisis as a global pandemic and national governments began to implement lockdown and quarantine measures globally in March 2020, public health authorities stressed that confinement institutions pose a critical challenge for anti-coronavirus policies. Prison facilities and other types of custodial sites were rapidly singled out as potential hotbeds for infection (Hawks et al. 2020; Hooks and Libel 2020; Hooks and Sawyer 2020). In fact, international organisations published guidelines providing advice to competent authorities on how to prevent the pandemic in these closed environments (WHO Europe 2020a).

In dealing with this concerning scenario, national administrations adopted a variety of policy agendas. Many countries imposed stringent quarantine restrictions, heightening the usual isolation of confinement facilities from the outside world. Therefore, both prisoners and immigration detainees were temporarily banned from receiving visits in many jurisdictions, sometimes with specific exceptions targeting lawyers and watchdog 
staff (see, e.g., Contrôleur Général des Lieux de Privation de Liberté CGLPL; Esposito et al. 2020; Home Office 2021). The Global Detention Project (GDP) COVID-19 Platform allows one to deduce that these quarantine measures gained particular traction in the course of the second and subsequent waves of the pandemic, when the "coronavirus fatigue" (WHO Europe 2020b) was beginning to affect national officials and infections behind bars were on the rise in various countries (Bulman 2021; Stuber and Zeier 2021; Vargas 2021).

In certain cases, these quarantine policies adopted xeno-racist and apartheid-like tones. In fact, anti-immigration agendas transpired in political decisions aimed at, e.g., completely closing off detention facilities and reception centres and extending quarantine measures targeting those facilities beyond national lockdown deadlines (International Commission of Jurists ICJ). Those practices frequently targeted overcrowded sites hosting particularly vulnerable asylum-seeking populations (Refugee Rights Europe 2020). These measures laid bare the "less eligibility" rationale (De Giorgi 2010) and the deterrence aims characterising immigration detention in many jurisdictions (Bosworth 2019; Campesi 2015; Leerkes and Broeders 2010), European and non-European alike.

These apartheid-like policies seem to have garnered particular traction in certain Mediterranean countries that have long disregarded human rights standards in enforcing their border policies such as Cyprus (Andreou 2021; European Council on Refugees and Exiles ECRE; Knews 2020a), Greece (Cossé 2020; International Commission of Jurists ICJ), and Malta (European Committee for the Prevention of Torture ECPT). ${ }^{3}$ However, this has not been the case everywhere. On the contrary, in other jurisdictions, anti-coronavirus strategies pointed to a different, almost opposite direction. In stark contrast to those thanatopolitical agendas (Vaughan-Williams 2015), various European jurisdictions chose to follow international organisations' recommendations (see, e.g., Commissioner for Human Rights 2020) by reducing the capacity of custodial facilities, thereby curtailing occupancy rates. This did not lead national authorities to open up new detention facilities, but to halve their total detention capacity almost overnight, a measure taken in countries such as Belgium (Carretero 2020; Global Detention Project GDP), Finland (European Migration Network EMN), France (La Cimade 2020), and Sweden (European Council on Refugees and Exiles ECRE; Lindberg et al. 2020).

Release strategies, in turn, were unequivocally advocated by the medical community (see Lopez et al. 2021; Macmadu et al. 2020), which gave preference to healthcare concerns over law enforcement considerations. However, this agenda was also championed by various other critical actors, claiming that an exceptional scenario like the global pandemic justified relegating border control interests (United Nations Working Group on Alternatives to Immigration Detention UNWGATD). In several European jurisdictions such as France, Italy, Portugal, Sweden, Switzerland, and the UK this demand was heralded by numerous ombuds officials (ANSA 2020), politicians and lawmakers (Cassidy 2020), NGOs and migrant rights organisations (Expresso 2020; FARR 2020; Inquest 2020; Lasciateentrare 2020; Solidarité Sans Frontières SSF; Taylor 2020a), and evidently detained noncitizens themselves (Knews 2021; Loran 2020; Shenker 2021).

This public health agenda was partly successful. At least in the first stages of the pandemic, many European nations witnessed a significant decline in the number of prisoners (DLA Piper 2021). Aebi and Tiago (2020) show that prison population rates dwindled by more than 5 percent in fourteen EU and European Free Trade Association (EFTA) countries from January to September 2020, and especially in Bulgaria, France, Italy, Lithuania, and Portugal. The causes of this decline were varied. Lockdown measures hampering regular judicial activities reduced prison admissions. In addition, European jurisdictions released significant contingents of prisoners for coronavirus prevention motives. Indeed, Cyprus, France, Norway, Portugal, Slovenia, and Spain freed more than 10 percent of their incarcerated populations for COVID-19 reasons over the first nine months of 2020 (Aebi and Tiago 2020). Beyond wide-ranging release programmes implemented in countries such as Iran (Hafezi 2020) and Turkey (Kucukgocmen 2020), also in the US anti-coronavirus measures resulted in a prison population drop. It has been estimated that state prison populations plummeted by 17 percent 
from January 2020 to January 2021, although it is not clear the extent to which this drop was due to pandemic-driven measures (Sharma et al. 2020; Widra 2021).

As is illustrated by Table 1, release policies gained also significant momentum in the immigration detention field. Certainly, not all EU and EFTA countries adopted this detention downsizing approach to prevent coronavirus infections. Available data (sources: GDP COVID-19 Platform; European Council on Refugees and Exiles ECRE; Fundamental Rights Agency FRA) show that many European countries (e.g., Austria, Bulgaria, the Czech Republic, Denmark, Greece, and Romania, amongst others) were reluctant to reduce the occupancy rate of detention facilities by freeing detained noncitizens. By contrast, the onset of the pandemic led detention populations to quickly drop in other European jurisdictions. In fact, in these immigration enforcement systems, far-reaching release policies led the number of detainees to drastically diminish in the course of a few weeks. The result of this sudden change was that the number of detainees was counted to be a couple of hundreds in spring 2020 in various European countries such as Belgium (Coppens 2020; European Migration Network EMN), Italy (Coalizione Italiana Libertà e Diritti Civili CILD; Esposito et al. 2020; Roman 2020), the Netherlands (NOS 2020), and Sweden (Lindberg et al. 2020), whilst in Germany (European Council on Refugees and Exiles ECRE), and Norway (European Migration Network EMN; Trandum Supervisory Board 2021), this number ultimately dropped to several dozens. France stood out in this regard as well, since the French administration closed down a dozen detention facilities in the first weeks of the pandemic (Contrôleur Général des Lieux de Privation de Liberté CGLPL; Conxicoeur 2020). In Switzerland, in turn, certain cantonal governments such as that of Geneva also closed down detention facilities, whereas others did not adopt wide-ranging release strategies (Tribune de Genève 2020). Additionally, UK authorities implemented far-reaching anti-coronavirus measures in the field of immigration detention. Widespread release procedures led the number of immigration detainees to decline by around 70 percent in just the two first months of the pandemic (Home Office 2020).

Table 1. European jurisdictions particularly affected by coronavirus-related immigration enforcement changes.

\begin{tabular}{cccc}
\hline $\begin{array}{c}\text { Significant Decline in the } \\
\text { Detention Population }\end{array}$ & $\begin{array}{c}\text { Detention Facilities } \\
\text { Almost Emptied }\end{array}$ & $\begin{array}{c}\text { Closure of all } \\
\text { Detention Facilities }\end{array}$ & $\begin{array}{c}\text { Deportations More than } \\
\text { Halved in 2020 }\end{array}$ \\
\hline $\begin{array}{c}\text { Belgium, France, Italy, the Netherlands, } \\
\text { Sweden, Switzerland, UK }\end{array}$ & Germany, Norway & Spain & $\begin{array}{c}\text { Bulgaria, France, Italy, Poland, } \\
\text { Slovakia, Spain }\end{array}$ \\
\hline
\end{tabular}

Sources: Eurostat (ec.europa.eu/eurostat/web/asylum-and-managed-migration/data/database; accessed on 4 May 2021), and various official and NGO reports, precisely referenced throughout the paper.

In addition to release procedures, occupancy rates were kept low by raising the threshold to impose detention measures and by excluding certain national groups from detention in several jurisdictions such as Finland, Norway and the UK (source: GDP COVID-19 Platform). Moreover, the number of issued removal decisions significantly declined in the vast majority of European jurisdictions in spring 2020 (European Migration Network EMN). Judicial actors, in turn, played a relatively significant role by both issuing release decisions and preventing the enforcement of detention measures in a number of jurisdictions such as France (Contrôleur Général des Lieux de Privation de Liberté CGLPL; Mucchielli 2020), Italy (Caprioglio and Rigo 2020; Roman 2020), and the UK (Harger 2020; Taylor 2020b). Specifically, the Swiss Federal Court handed down several critical decisions in this regard in June and July 2020 (24 Heures 2020a, 2020b).

Despite the relevant impact of these anti-coronavirus efforts on the immigration enforcement landscape, initiatives aimed at liberating all detained noncitizens and temporarily shutting down all detention facilities failed in a number of EU countries. This was the case in France, where a demand championed by ombudspersons (Contrôleur Général des Lieux de Privation de Liberté CGLPL), NGOs and lawyers (Observatoire de l'enfermement des étrangers OEE) was rejected by the Council of State, which considered it legally unjustified, in late March 2020 (Lecadre 2020). Likewise, in Britain, a legal challenge 
filed by a pro-migrant rights group (Detention Action 2020) was not upheld by the UK High Court, arguing that the number of released noncitizens was enough to safeguard detainees' right to healthcare (Ironmonger 2020).

\section{Coronavirus and the Temporary Moratorium on Immigration Detention}

In spite of the aforementioned institutional efforts, in Europe-as well as in the US- 4 anti-coronavirus policies fell short of imposing a moratorium on immigration detention and temporarily shutting custodial facilities. This was also the official stance adopted by the European Commission, which recommended EU member states to issue release decisions on a case-by-case basis (European Commission 2020a). The only exception to this widespread trend was the Spanish case (Jesuit Refugee Service JRS), since the Spanish administration actually released all detained immigrants and shut down its seven detention facilities on 6 May 2020 (Fernández-Bessa 2021; Martín 2020).

Spain has a long consolidated and relatively sizeable immigration enforcement system, which detains and deports significant contingents of unwanted noncitizens. More precisely, 132,448 noncitizens were confined in Spanish detention facilities from 2008 to 2019 (Fernández-Bessa 2021), and 214,470 foreign nationals were removed from Spain over the same twelve-year period (source: Eurostat). However, both dimensions of the mobility control apparatus have been shrinking in the recent past. The annual number of immigration detainees dwindled by 73.9 percent and that of removals declined by 58.5 percent from 2008 and 2019 (sources: Fernández-Bessa 2021; Eurostat). In stark contrast to this decline, Spain has witnessed a noteworthy increase in irregular border-crossing activities, particularly fuelled by the surge in the number of sea arrivals (Barbero Forthcoming), 5 which have had a significant impact on the Canary Islands in 2020 and 2021.

In Spain, immediately after the declaration of the state of alarm in mid-March 2020, various actors put the spotlight on the health measures to be taken in the field of immigration detention. Both migrant rights groups (Cies No 2020) and the National Ombudsman (Sainz 2020) called for the swift release of all detainees (see also Lopez-Sala 2021). The Spanish Minister of the Interior did not show an outright opposition to this demand; however, he claimed that release measures should be individually considered, rejecting any all-encompassing decision (Europa Press 2020a). However, the immigration enforcement scenario changed more rapidly than expected. Judicial actors stepped in issuing release injunctions based on the unsuitable sanitary conditions of detention facilities (Vargas 2020). By early April 2020, only 34 noncitizens remained in custody; four out of seven Spanish detention settings, including those of Madrid and Barcelona, had already been closed (Europa Press 2020b). Finally, less than eight weeks since the onset of the state of alarm, the last detainees were released in early May 2020 from CIE Algeciras, the detention facility located at the southern border. Spanish confinement facilities remained closed over a 4-month summer, until 23 September 2020 (Fernández-Bessa 2021; Muñoz and Vargas 2020). One month thereafter, the Spanish detention facilities were confining 186 noncitizens, the majority of whom had been detected while irregularly crossing the southern border (Sánchez 2020a). Reopening policies were gradually implemented, leading some detention sites to be put into operation again only in early 2021 (Fernández 2021).

Widespread release practices, and particularly the closure of the Spanish immigration detention estate are unexpected events that raise a number of questions. First, the forces contributing to the implementation of until recently unthinkable policies-which were not extended to the prison field-should be further scrutinised. This exploration may gain further insight into the nature, characteristics and operation of immigration detention policies in Europe. Second, the potentially lasting legacy of these exceptional events should be examined. This point will be analysed in the last section, whilst the remaining part focuses on the previous dilemma.

Crimmigration and border criminology scholars have long called into question the administrative law nature of immigration detention (Barker 2017; Bosworth 2019; García Hernández 2014), which is regulated as a precautionary measure exclusively aimed at 
preparing the eventual enforcement of a deportation order in the European case (Aas 2014; Bosworth 2012; Campesi 2013). Paradoxically, this legal nature was the basis of the far-reaching release schemes enacted in various European jurisdictions. The onset of the pandemic led to the immediate closure of borders in many countries, including global south countries of origin of irregular flows. This sudden re-bordering agenda made deportations unfeasible for some months in mid-2020, especially return procedures carried out by air and sea (European Migration Network EMN; Majkowska-Tomkin 2020). ${ }^{6}$ The legal consequence of this unseen scenario is unambiguously laid down by Article 15(4) of the Return Directive (Directive 2008/115/EC of the European Parliament and of the Council of 16 December 2008), i.e., detained noncitizens must be immediately released when " ... reasonable prospect of removal no longer exist ... " (see Mitsilegas 2015; see also International Commission of Jurists ICJ).

The purposes of immigration detention policies have long been debated by the extant literature, which has elaborated a variety of theses on this topic. Border criminology scholars have scrutinised various immigration detention functions, both instrumental and symbolic, such as the management of destitute populations, the policing of membership boundaries, and the strengthening of national sovereignty (Bosworth 2019; Leerkes and Broeders 2010). The crimmigration thesis, in turn, underlines that immigration detention is being increasingly used for crime prevention purposes, rather than for its traditional mission related to immigration law breaches (García Hernández 2014; Turnbull 2017; see also Zedner 2016). Other authors embrace what might be called a "general deterrence" viewpoint, in which detention practices are geared towards dissuading unwanted noncitizens from coming, settling and staying in a given (national) community (Bosworth 2019; Campesi 2015; Leerkes and Broeders 2010). In addition, another strand of literature brings to the fore "special deterrence" goals, by claiming that detention policies are aimed at coercively persuading targeted noncitizens "to leave", by either collaborating in preparing their forced removals or signing in for so-called "voluntary return" programmes (Hasselberg 2016; Leerkes and Kox 2017; Martínez et al. 2018).

However, the public health crisis led the legal nature of immigration detention as a preremoval precautionary measure to take precedence over any other detention goal. In fact, the extra-legal notion according to which detention procedures are also used to confine and incapacitate high-risk noncitizens, e.g., former prisoners, was only exceptionally alleged by certain national authorities in countries such as Belgium (Coppens 2020), Finland, the Netherlands (source: GDP COVID-19 Platform), and the UK (Ironmonger 2020) to justify the issuance or extension of detention orders (see though Esposito et al. 2020).

This analysis of the factors conditioning the immigration detention decline should also scrutinise why Spain was the only global north country closing down its detention sites in the framework of the pandemic. Immediately after Italy, Spain was one of the first European countries to be hardest hit by the COVID-19 pandemic. The MIPEX index ranks Spain relatively high in terms of migrant integration policies. In addition, despite the recent electoral impetus of the anti-immigration sentiments of far-right political party Vox, they do not seem to be particularly widespread in the Spanish case, if compared with other global north countries (D'Ancona 2016; Wonders 2017). Beyond all these background conditions, two more specific issues are what determined the exceptional decisions made by the Spanish authorities in the spring-summer of 2020. Their approach to anti-coronavirus measures in the field of immigration detention was particularly conditioned by legal provisions on the maximum length of detention (Piser 2020; Roman 2020). In Europe, detention time may be currently unlimited only in Ireland and the UK. These exceptional cases aside, detention time limits vary greatly among EU and EFTA countries. In the framework of these variations, Portugal and Spain have the shortest time limit, i.e., two months of detention, followed by France, with a three-month limit (Majcher et al. 2020). Consequently, especially tight time constraints played a pivotal role in the detention decline witnessed in the Spanish case. 
Additionally, the impact of public health policies on the deportation field was also critical in fostering a temporary moratorium on immigration detention. Evidently, border closures and international travel restrictions dramatically affected removal activities in many European jurisdictions. However, a wide number of European jurisdictions such as Belgium, Cyprus (Knews 2020b), Finland, France (Contrôleur Général des Lieux de Privation de Liberté CGLPL), Germany (InfoMigrants 2020), the Netherlands, Norway, Poland, Portugal, Switzerland, and the UK managed to avoid a complete halt of their deportation practices even in the worst phases of the coronavirus pandemic (sources: GDP COVID-19 Platform; European Council on Refugees and Exiles ECRE; European Migration Network EMN; Fundamental Rights Agency FRA). Bulgaria, Croatia, Estonia, Slovakia and other countries, in turn, continued carrying out removals by land to neighbouring countries in spring 2020 (sources: GDP COVID-19 Platform; European Migration Network EMN; Fundamental Rights Agency FRA). In some jurisdictions, so-called Dublin returns aimed at re-settling asylum seekers among EU countries were particularly affected but other types of removals were not wholly hampered by travel ban provisions. Eurostat data also confirm that at least Greece, Italy, Poland, Slovenia, Sweden and the UK carried out hundreds of removals in the second quarter of 2020. ${ }^{7}$ All in all, this official database reports that in various jurisdictions such as Bulgaria, France, Italy, Poland, and Slovakia the number of deportations was more than halved from 2019 to 2020, whilst in many other countries (Austria, Belgium, Croatia, Germany, Greece, Ireland, Latvia, Lithuania, the Netherlands, Romania, among others) this decline was from 20 percent to 50 percent. $^{8}$

In Spain, the number of deportations dwindled by 57.5 percent from 2019 to 2020 (source: Eurostat). However, the aforementioned data show that Spain was not the only European country forced to scale down its removal practices. Consequently, the specific configuration of deportation policies in the Spanish case is what actually contributed to the enactment of a migration detention moratorium. In a jurisdiction suffering a significant “deportation gap" (Gibney 2008; Rosenberger and Küffner 2016) such as Spain, ${ }^{9}$ deportation procedures are particularly and increasingly targeted. Removal operations carried out by land to neighbouring countries are irrelevant in the Spanish case. By contrast, return procedures targeting Moroccan and Algerian nationals make up the lion's share of Spanish deportation policies (Fernández-Bessa 2021; Fernández Bessa and Brandariz 2018); these two national groups combined accounted for 62.8 percent of the removal orders enforced in Spain from 2015 to 2019. ${ }^{10}$ Therefore, the measures rapidly adopted in these countries and other critical countries for Spanish deportation policies such as Colombia to close borders and suspend international travel undermined the legal grounds of detention practices (Orejudo 2020).

Having said that, an additional point should be taken into consideration to understand immigration enforcement changes in Spain. In a country lacking a consolidated, farreaching network of reception facilities, Spanish law enforcement agencies have long channelled immigrant and asylum-seeking newcomers into detention sites (FernándezBessa 2021). Evidently, the pandemic led to a significant change in the field of migration policing, since detected undocumented noncitizens were not directed towards detention resources any longer. ${ }^{11}$ By contrast, irregular border-crossers were hosted in makeshift reception facilities and largely confined in the Canary Islands. ${ }^{12}$ Surely, this migration policing shift was partly fostered by more general policing changes implemented in the framework of the anti-covid policy agenda. In fact, the Spanish administration concentrated policing resources in deploying an arguably unprecedented operation aimed at monitoring and penalising quarantine and lockdown breaches in spring 2020 (López-Riba 2020).

In sum, national policy agendas resulted in marked variations in the ways in which European states tackled infection risks in the field of immigration detention. This is unsurprising, since the multi-scalar nature of mobility governance in Europe (Brandariz and Fernández-Bessa 2020; Moffette 2018; Wonders 2017) gives shape to a notably diverse migration enforcement scenario (Brandariz 2021). This diversity was surely compounded by the re-bordering processes fuelled by the coronavirus pandemic, which reinforced 
chauvinist perspectives and agendas in managing the public health emergency. In this variegated framework, the Spanish administration went as far as to empty all detention facilities for a 4-month-and-17-day period. After having explored the forces and conditions contributing to that exceptional decision, the last section reflects on whether the widespread release practices set in motion in mid-2020 may pave the way for an enduring immigration detention decline in Europe.

\section{Concluding Remarks: The Short Summer of Abolitionism?}

In 1972, the German writer Hans Magnus Enzensberger published his book The Short Summer of Anarchy (Der Kurze Sommer der Anarchie). In between fiction and document, Enzensberger's essay narrates the life and death of the Spanish anarchist leader Buenaventura Durruti, with a special focus on the exceptional events that occurred in the summer of 1936. Back then, against the backdrop of the initial stages of the Spanish Civil War (1936-1939), anarchist activists and organisations engaged in a widespread revolutionary effort that actually eroded the capitalist rule in several Eastern Spain regions. This revolutionary impetus, though, did not last much longer than a short summer, before being completely defeated in spring 1937.

In a loose analogy to Enzensberger's book, a question arises as to whether the groundbreaking detention policies enacted in 2020 may reverberate beyond the brief summer of its legal validity (see also Roman 2020; Weber 2020). Certain evidence may lead one to infer that what happened in the European immigration detention scenario in mid-2020 was actually unique and unrepeatable. Despite the long-lasting impact of the public health crisis, immigration enforcement practices seem to have been largely brought back on track throughout Europe (Fundamental Rights Agency FRA; European Migration Network EMN; Jesuit Refugee Service JRS). Even in Spain, deportation practices resumed in late 2020 (Sánchez 2020b). In addition, a close look at what has happened inside the Spanish reception facilities located in northern Africa prevents any naïve conclusion associating Spain's immigration detention policies with any new, human rights-based agenda in the field of border and mobility management policies. In stark contrast to its approach to immigration detention, the Spanish Ministry of the Interior left the reception centres located in the enclave towns of Ceuta and Melilla unattended, ${ }^{13}$ although the noncitizens sheltered in place had to cope with quarantine measures in these overcrowded and degraded facilities (Amnesty International 2020; Council of Europe 2020). This concerning scenario resonates with what has been happening in the Canary Islands since autumn 2020. A surge in the number of arrivals in the archipelago has been met by the Spanish administration by providing substandard reception conditions and impeding newcomers from travelling to the mainland (see, e.g., MacGregor 2021; Martín 2021; Human Rights Watch HRW). At least in this regard, the Spanish case is no exception. On the contrary, the policies adopted by Spain to tackle mobility flows have been worryingly similar to those recently implemented in other Mediterranean countries such as Cyprus and Greece.

These unpromising signs apparently forecast a rapid return to a business-as-usual scenario in immigration enforcement policies. However, there are certain reasons to think that what happened in the immigration detention field may actually reverberate well beyond the brief summer of 2020, having lasting consequences. In political terms, the pandemic created suitable conditions to spotlight detention practices and to rally a broad variety of actors behind an agenda aimed at putting human rights before border control interests. In empirical terms, the events of 2020 have been incidentally hailed as a pathway to detention abolition (Fialho and Moreno 2020). This may be an overstatement, especially if detention abolition is seen in the framework of a more far-reaching effort to abolish the carceral state (on this notion of prison abolition see García Hernández 2017; Shah 2021; Ybarra 2021). However, those events may operate as a humble albeit promising precedent, since national and EU authorities have verified that a significant reduction in the immigration detention estate does not lead the immigration enforcement apparatus to collapse (Esposito et al. 2020; Harger 2020; Saiz 2020). Consequently, this precedent 
might work as a political and policy resource to be leveraged for abolition purposes; in other words, it should be used to advocate a sharp, gradual and incremental reduction in immigration detention. In legal terms, what happened in Spain and other Western and Northern European countries in mid-2020 gave a significant boost to some easily overlooked legal principles regulating immigration detention in Europe. First, detention measures can only be imposed to prepare an eventual removal (Art. 15(1) and 15(5) of the Return Directive). Consequently, these law enforcement measures cannot be legally used to pursue any other competing goal, not even public protection purposes. Second, detention measures are not legally justified when other less coercive measures may warrant the eventual enforcement of the corresponding removal order (Art. 15(1) of the Return Directive). Third, detainees have to be released as soon as " . . a reasonable prospect of removal no longer exists ... " (Art. 15(4) of the Return Directive; see also Article 5(1)(f) of the European Convention on Human Rights).

Were this handful of legal tenets to be seriously taken into consideration, as it happened in 2020, they might significantly and enduringly alter the immigration detention landscape in Europe. As has been officially recognised (European Commission 2017, 2020b), a number of European jurisdictions are notably inefficient in enforcing their crimmigration policies. Eurostat data show that Belgium, Bulgaria, the Czech Republic, France, Italy, and Portugal had an average enforcement rate lower than 30 percent from 2008 to 2019. Detention policies do not seem to be of much use in bridging that deportation gap. In fact, in various European countries, wide swathes of the detained populations are placed under custody for relatively long periods without reasonable prospects of eventual deportation. Therefore, detention policies have long proven to be relatively ineffective, for significant percentages of detainees end up being released—or bailed-instead of deported. In Britain, 48.4 percent of the noncitizens detained from 2010 to 2019 were not removed but released on bail or after having been granted a leave to remain (source: Home Office; www.gov.uk/government/statistics/immigration-statistics-year-ending-march2020/how-many-people-are-detained-or-returned; accessed on 19 April 2021). What is more, the removal rate has been constantly declining since the early 2010s. In the Spanish case, it is estimated that 50.5 percent of the undocumented noncitizens detained from 2010 to 2019 were not subsequently deported (Fernández-Bessa 2021). Similarly, official data report that no more than 49.8 percent of the detainees placed under custody in Italy from 2017 to 2019 were eventually removed (source: Garante Nazionale dei diritti delle persona detenute; www.garantenazionaleprivatiliberta.it/gnpl/it/pub_rel_par.page; accessed on 19 April 2021). Detention policies are even slightly less effective in a country such as France, which combines a sizeable immigration detention estate and relatively low deportation enforcement rates. La Cimade reports (www.lacimade.org/publication/?type-publication= rapports-sur-la-retention-administrative; accessed on 19 April 2021) estimate that only 45.6 percent of the noncitizens confined in French detention facilities from 2010 to 2019 were ultimately removed.

Although national and EU authorities are long aware of these shortcomings, they do not seem to be particularly willing to bring detention policies in line with EU (and national) law provisions. However, current detention strategies are untenable in both managerial and legal terms. The partly useless nature of detention practices for deportation practices has long been addressed by stressing that immigration detention actually pursues a number of goals unrelated to removal procedures themselves (Fernández-Bessa 2021). However, coronavirus-era detention policies have eroded the standing of these extra-legal purposes. Consequently, what happened in 2020 should be leveraged to significantly reduce the immigration detention estate in Europe, which has proven to be-at leastpartly dispensable to carry out mobility management tasks. Those coronavirus-related events showed that this aspiration may join a broad variety of actors in the political and public sphere. This political agenda may be buttressed by a very simple fact, i.e., in contrast to what may be thought, not all EU and EFTA countries have sizeable detention systems (Brandariz 2021). In fact, national detention apparatuses are relatively tiny and 
narrow-ranging not only in small countries such as Estonia and Latvia but also in the Czech Republic, Ireland, Romania, and - to a certain extent-Germany and Italy (source: GDP data; www.globaldetentionproject.org/regions-subregions/europe; accessed 15 April 2021). Eurostat data confirm that these parsimonious detention policies do not inevitably lead those countries to rank particularly low in terms of either deportation numbers or deportation enforcement rates. ${ }^{14}$ These cases, therefore, illustrate that EU jurisdictions may dispense away with or at least significantly curtail their detention systems without seriously compromising their border control policies (see also Piser 2020).

In stark contrast to the re-bordering processes triggered by the pandemic, this paper aimed to show that we should adopt a cross-national perspective in rethinking detention policies. The supranational level may supply key political and legal tools to build an immigration enforcement system focusing on alternatives to detention rather than on detention practices. This effort might take stock of the migration detention arrangements tested in the framework of the pandemic. In so doing, the events of 2020 would work as a powerful precedent, not as a memento of an increasingly distant, short summer in which immigration detention seemed to be a vulnerable carceral institution.

Author Contributions: J.A.B. explored detention changes across Europe (Section 2), whilst C.F.B. scrutinised the Spanish case (Section 3). Both authors co-authored the introduction (Section 1) and the conclusions (Section 4). Both authors have read and agreed to the published version of the manuscript.

Funding: This research received no external funding.

Institutional Review Board Statement: Not applicable.

Informed Consent Statement: Not applicable.

Data Availability Statement: Publicly available datasets were analyzed in this study. This data can be found here: Eurostat. Asylum and managed migration data, ec.europa.eu/eurostat/web/ asylum-and-managed-migration/data/database; Garante Nazionale dei diritti delle persona detenute, www.garantenazionaleprivatiliberta.it/gnpl/it/pub_rel_par.page; Global Detention Project, www.globaldetentionproject.org/regions-subregions/europe; Home Office, www.gov.uk/government/ statistics/immigration-statistics-year-ending-march-2020/how-many-people-are-detained-or-returned; La Cimade, www.lacimade.org/publication/?type-publication=rapports-sur-la-retention-administrative; Migration Integration Policy Index, www.mipex.eu; National Mechanism for the Prevention of Torture; www.defensordelpueblo.es/informe-mnp/mecanismo-nacional-prevencion-la-tortura-informeanual-2019/; Spanish Ministry of the Interior, www.interior.gob.es/gl/prensa/balances-e-informes/20 20; UNHCR, data2.unhcr.org/en/situations/mediterranean/location/5226. (Links are accessed on 19 April 2021).

Acknowledgments: We thank the two anonymous reviewers and the editor of this special issue, Robert Koulish (University of Maryland, US), for their support and recommendations in preparing this article.

Conflicts of Interest: The authors declare no conflict of interest.

\section{Notes}

1 On cross-border mobility restrictions implemented since mid-2020 see the KPMG (assets.kpmg/content/dam/ kpmg/xx/pdf $/ 20$ 20/05/Interactive-GMS-Covid-Tracker.pdf; accessed on 19 April 2021) and nccr-on the move (public.tableau.com/profile/nccr. on.the.move\#!/vizhome/Covid-19outbreak_15843550159920/Lists; accessed on 19 April 2021) databases.

2 Specifically, the Global Detention Project (GDP) Covid-19 Platform (www.globaldetentionproject.org/covid-19-immigrationdetention-platform; accessed on 7 April 2021) was a critical source of information for this study. In a peculiar period in which scholars were largely unaware of what was happening beyond their national borders, this platform provided vital information to carry out comparative explorations.

3 The Migration Integration Policy Index 2020 ranks these three Mediterranean countries very low in terms of integration policies, well below the vast majority of Western and Nordic European nations and many other non-European jurisdictions such as Canada, New Zealand, Australia, USA, Brazil, and Argentina (see www.mipex.eu/; accessed on 8 April 2021).

4 Release policies apparently garnered less traction in the US than in various Western and Northern European countries. However, also in the US the combination of an ongoing deportation effort with the scaling down of migration policing arrests resulted 
in a significant decline in the number of detained noncitizens in mid-2020 (European Migration Network EMN). In fact, it is estimated that the US detained population dwindled by 42.5 per cent from late March to late July 2020 (Kerwin 2020; see also Erfani et al. 2021; Tosh et al. 2021).

5 UNHCR data show that the number of irregular sea arrivals mounted from 8162 in 2016 to 40,326 in 2020, after having peaked at 58,569 in 2018 (see data2.unhcr.org/en/situations/mediterranean/location/5226; accessed on 28 May 2021). The clousure of the Eastern and central Mediterranean routes following the agreements between the EU and Turkey and between Italy and Lybia since 2017 has particularly contributed to this surge.

6 Deportation restrictions made a relevant difference between European cases and the US case. The US administration managed to keep its deportation routes with global south countries relatively open even in the framework of the especially severe border closures imposed in the first wave of the pandemic. In fact, it is estimated that around 40,000 noncitizens were deported from the US in spring 2020 (Kassie and Marcolini 2020; see also European Migration Network EMN; Kerwin 2020).

7 Poland, Slovenia and Sweden were also particularly active in this field in the summer of 2020 (source: Eurostat; see also Fundamental Rights Agency FRA). By contrast, the European Migration Network reports (European Migration Network EMN) that the number of deportations only returned to pre-pandemic levels in summer 2020 in Cyprus, the Czech Republic, Poland, and Switzerland.

8 Paradoxically, the number of enforced deportations rose from 2019 to 2020 in the Czech Republic, and especially in Cyprus and Hungary.

9 In Spain, only 32.5 per cent of the issued deportation orders were actually enforced from 2008 to 2019 (source: Eurostat. Asylum and managed migration data).

10 Moroccan and Algerian nationals combined accounted for 44.1 per cent of the undocumented noncitizens under custody in Spanish detention facilities from 2014 to 2018 (Fernández-Bessa 2021). In addition, these two national groups accounted for 75.2 per cent of the noncitizens deported from Spain in 2019 after having been confined in one of the seven pre-removal facilities (source: National Mechanism for the Prevention of Torture; www.defensordelpueblo.es/informe-mnp/mecanismo-nacionalprevencion-la-tortura-informe-anual-2019/; accessed on 16 April 2021).

11 The Spanish Ministry of the Interior data (see www.interior.gob.es/gl/prensa/balances-e-informes/2020; accessed on 14 April 2021) show that around 12,750 irregular border-crossers arrived to Spain from 1 May 2020 to 30 September 2020.

12 In 2020, more than 23,000 noncitizens arrived to the Canary Islands, a Spanish archipelago in the Atlantic Ocean which is relatively close to the Western Sahara's coastline. Since August 2020, these border-crossers were hosted in an emergency camp sited in the Arguineguín pier, Grand Canary, which was set up for medical screening-including COVID-19 testing, police identification and registration purposes. This substandard facility was bitterly criticised by the Spanish Ombudsman, HRW, and other NGOs, for both its overcrowding and unsanitary conditions and the violation of asylum and police custody provisions. Empty hotel rooms were also used as an emergency accommodation solution in summer 2020. Both hotel rooms and the precarious Arguineguín facility were replaced with a new custodial centre, the Barranco Seco CATE, and with the transformation of former factories and administrative buildings into reception facilities since November 2020 (see Human Rights Watch HRW; Gobierno de España 2020).

13 The Spanish enclaves of Ceuta and Melilla are located in northern Africa and sorrounded by razor-wired border walls. Both towns have reception facilities called CETI (for their initials in Spanish), which are aimed at hosting mainly asylum seeking bordercrossers while they are awaiting either to receive an international protection decision or to be transferred to the Iberian peninsula.

14 As far as the number of enforced deportations is concerned, the majority of the mentioned jurisdictions does not play a leading role in the European deportation apparatus; Germany, though, is a top deporting country. In terms of enforcement rates, the Czech Republic, Italy, and also Ireland have relatively low rates, whereas Estonia, Germany, Latvia, and Romania are particularly efficient in enforcing their deportation orders.

\section{References}

24 Heures. 2020a. Le TF Critique la Détention en vue du Renvoi. 24 Heures. Available online: www.24heures.ch/le-tf-critique-ladetention-en-vue-du-renvoi-352216366834 (accessed on 12 April 2021).

24 Heures. 2020b. Asile: Pas de Détention si le Renvoi est empêché par le Coronavirus. 24 Heures. Available online: www.24heures.ch/ asile-pas-de-detention-si-le-renvoi-est-empeche-par-le-coronavirus-783597632491 (accessed on 12 April 2021).

Aas, Katja Franko. 2014. Bordered Penality: Precarious Membership and Abnormal Justice. Punishment E Society 16: $520-41$.

Aebi, Marcelo Fernando, and Mélanie Tiago. 2020. Prisons and Prisoners in Europe in Pandemic Times: An Evaluation of the Medium-Term Impact of the COVID-19 on Prison Populations. Strasbourg: Council of Europe, Available online: https://wp.unil.ch/space/files/20 21/02/Prisons-and-the-COVID-19_2nd-Publication_201109.pdf (accessed on 8 April 2021).

Amnesty International. 2020. Es Urgente el Traslado y Realojo en Condiciones Dignas de las Personas Migrantes y Solicitantes de Asilo en Melilla. Available online: www.es.amnesty.org/en-que-estamos/noticias/noticia/articulo/es-urgente-el-traslado-y-realojoen-condiciones-dignas-de-las-personas-migrantes-y-solicitantes-de-a/ (accessed on 15 April 2021).

Andreou, Evie. 2021. UN agency Calls for Decongestion of Migrant Camp after Brawl. Cyprus Mail. Available online: https: / / cyprus-mail.com/2021/01/13/eu-asylum-support-office-sending-more-personnel-to-cyprus/ (accessed on 9 April 2021).

ANSA. 2020. Coronavirus: Italian Detainee Rights Guarantor Concerned about Migrants in Repatriation Centers. InfoMigrants. Available online: www.infomigrants.net/en/post/23685/coronavirus-italian-detainee-rights-guarantor-concerned-about-migrantsin-repatriation-centers (accessed on 9 April 2021). 
Barbero, Iker. Forthcoming. Los Centros de Atención Temporal de Extranjeros como nuevo modelo de gestión migratorio: Situación actual, (des)regulación jurídica y mecanismos de control de derechos y garantías. Derechos y Libertades 45.

Barker, Vanessa. 2017. Penal Power at the Border: Realigning State and Nation. Theoretical Criminology 21: 441-57. [CrossRef]

Bosworth, Mary. 2012. Subjectivity and Identity in Detention: Punishment and Society in a Global Age. Theoretical Criminology 16: 123-40. [CrossRef]

Bosworth, Mary. 2019. Immigration Detention, Punishment and the Transformation of Justice. Social and Legal Studies 28: 81-99. [CrossRef]

Brandariz, José Ángel. 2021. An expanded analytical gaze on penal power: Border criminology and punitiveness. International Journal for Crime, Justice and Social Democracy 10: 99-112. [CrossRef]

Brandariz, José Ángel, and Cristina Fernández-Bessa. 2020. A changing and multi-scalar EU borderscape: The expansion of asylum and the normalisation of the deportation of EU and EFTA citizens. International Journal for Crime, Justice and Social Democracy 9: 21-33. [CrossRef]

Bulman, May. 2021. Immigration Detention Centre Forced to Close due to Covid Outbreak. The Independent. Available online: www. independent.co.uk/news/uk/home-news/immigration-detention-centre-closed-covid-outbreak-home-office-b1784499.html (accessed on 18 April 2021).

Campesi, Giuseppe. 2013. La detenzione Amministrativa degli Stranieri: Storia, Diritto, Politica. Roma: Carocci.

Campesi, Giuseppe. 2015. Hindering the Deportation Machine: An Ethnography of Power and Resistance in Immigration Detention. Punishment E Society 17: 427-53.

Caprioglio, Carlo, and Enrica Rigo. 2020. Le Restrizioni alla Libertà di Movimento ai Tempi del Covid-19. Questione Giustizia. Available online: www.questionegiustizia.it/articolo/le-restrizioni-alla-liberta-di-movimento-ai-tempi-del-covid-19_30-03-2 020.php (accessed on 9 April 2021).

Carretero, Leslie. 2020. Coronavirus: En Belgique, “l’Etat ne fait rien pour protéger les migrants". InfoMigrants. Available online: www.infomigrants.net/fr/post/23785/coronavirus-en-belgique-l-etat-ne-fait-rien-pour-proteger-les-migrants (accessed on 9 April 2021).

Cassidy, Jane. 2020. Alison Thewliss Urges Release of Immigration Detainees. The National. Available online: www.thenational.scot/ news/18375848.alison-thewliss-urges-release-immigration-detainees / (accessed on 12 April 2021).

Contrôleur Général des Lieux de Privation de Liberté (CGLPL). 2020. Les Droits Fondamentaux des Personnes Privées de Liberté à l'épreuve de la Crise Sanitaire: 17 Mars au 10 Juin 2020. Available online: www.cglpl.fr/wp-content/uploads/2020/07/CGLPL_ Rapport-COVID.pdf (accessed on 9 April 2021).

Chew, Vivienne, Melissa Phillips, and Min Yamada Park, eds. 2020. COVID-19 Impacts on Immigration Detention: Global Responses. Sydney: International Detention Coalition and HADRI/Western Sydney University, Available online: Idcoalition.org/wp-content/ uploads/2020/10/COVID-19-Impacts-on-Immigration-Detention-Global-Responses-2020.pdf (accessed on 16 April 2021).

Cies No. 2020. Ante el Coronavirus, Exigimos la Libertad para las Personas Internas en los Centros de Internamiento de Extranjeros. Available online: Ciesno.wordpress.com/2020/03/13/ante-el-coronavirus-exigimos-la-libertad-para-las-personas-internasen-los-centros-de-internamiento-de-extranjeros / (accessed on 13 April 2021).

Coalizione Italiana Libertà e Diritti Civili (CILD). 2020. Detenzione Migrante ai Tempi del Covid. Available online: https:/ / cild.eu / wp-content/uploads/2020/07/Dossier_MigrantiCovid.pdf (accessed on 21 April 2021).

Commissioner for Human Rights. 2020. Council of Europe. Commissioner Calls for Release of Immigration Detainees While Covid-19 Crisis Continues. Available online: www.coe.int/en/web/commissioner/thematic-work/covid-19/-_/asset_publisher/5cdZW0 AJBMLl/content/commissioner-calls-for-release-of-immigration-detainees-while-covid-19-crisis-continues?inheritRedirect=

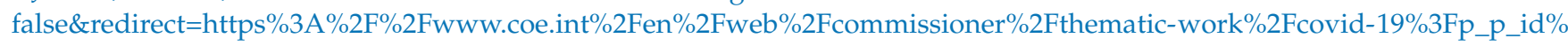
3D101_INSTANCE_5cdZW0AJBML1\%26p_p_lifecycle\%3D0\%26p_p_state\%3Dnormal\%26p_p_mode\%3Dview\%26p_p_col_ id\%3Dcolumn-1\%26p_p_col_count\%3D1 (accessed on 9 April 2020).

Connor, Phillip. 2020. More than Nine-in-Ten People Worldwide Live in Countries with Travel Restrictions Amid COVID-19. Washington, DC: Pew Research Centre, Available online: www.pewresearch.org/fact-tank/2020/04/01/more-than-nine-in-ten-peopleworldwide-live-in-countries-with-travel-restrictions-amid-covid-19/ (accessed on 14 April 2021).

Conxicoeur, Christian. 2020. Coronavirus Covid-19: Le Centre de rétention Administrative de Lyon Presque Entièrement évacué. France Info. Available online: https:/ / france3-regions.francetvinfo.fr/auvergne-rhone-alpes/rhone/lyon/coronavirus-covid-19 -centre-retention-administrative-lyon-presque-entierement-evacue-1805022.html (accessed on 9 April 2021).

Coppens, Marc. 2020. 200 illegale personen op vrije voeten als gevolg van coronacrisis. HLN. Available online: www.hln.be/ binnenland / 200-illegale-personen-op-vrije-voeten-als-gevolg-van-coronacrisis $\sim\{$ a1b17321/?referer=https $\% 3 \mathrm{~A} \% 2 \mathrm{~F} \% 2 \mathrm{Ft} . c 0 \%$ 2FKoFwOrmDFr\%3Famp\%3D1 (accessed on 9 April 2021).

Cossé, Eva. 2020. Greece Again Extends Covid-19 Lockdown at Refugee Camps. Human Rights Watch. Available online: www.hrw.org/ news/2020/06/12/greece-again-extends-covid-19-lockdown-refugee-camps (accessed on 9 April 2021).

Council of Europe. 2020. Spain's Authorities Must Find Alternatives to Accommodating Migrants, Including Asylum Seekers, in Substandard Conditions in Melilla. Available online: www.coe.int/en/web/commissioner/-/spain-s-authorities-mustfind-alternatives-to-accommodating-migrants-including-asylum-seekers-in-substandard-conditions-in-melilla (accessed on 15 April 2021). 
D’Ancona, María Ángeles Cea. 2016. Immigration as a threat: Explaining the changing pattern of xenophobia in Spain. Journal of International Migration and Integration 17: 569-91. [CrossRef]

De Giorgi, Alessandro. 2010. Immigration control, post-Fordism, and less eligibility: A materialist critique of the criminalization of immigration across Europe. Punishment \& Society 12: 147-67.

Dehm, Sara. 2020. The Entrenchment of the Medical Border in Pandemic Times. Border Criminologies. Available online: www.law.ox. ac.uk/research-subject-groups / centre-criminology/centreborder-criminologies/blog/2020/07/entrenchment (accessed on 7 April 2021).

Detention Action. 2020. Covid-19: People Must Be Released from Detention. Legal Challenge and Petition. Available online: Detention.org.uk/covid-19-people-must-be-released-from-detention-legal-challenge-and-petition/ (accessed on 12 April 2021).

DLA Piper. 2021. A Global Analysis of Prisoner Releases in Response to COVID-19. Available online: www.dlapiper.com/en/france/ news /2021/03/swift-targeted-action-to-reduce-prison-population-during-covid-19/ (accessed on 31 May 2021).

European Committee for the Prevention of Torture (ECPT). 2021. Report to the Maltese Government on the Visit to Malta Carried Out by the European Committee for the Prevention of Torture and Inhuman or Degrading Treatment or Punishment (CPT) from 17 to 22 September 2020. CPT/Inf (2021) 1. Available online: https://rm.coe.int/1680a1b877 (accessed on 12 April 2021).

European Council on Refugees and Exiles (ECRE). 2020. Information Sheet 5 May 2020: Covid-19 Measures Related to Asylum and Migration across Europe. Available online: www.ecre.org/wp-content/uploads/2020/05/COVID-INFO-5-May-.pdf (accessed on 9 April 2020).

European Migration Network (EMN). 2020. Special Annex to the 30th EMN Bulletin. EU Member States \& Norway: Responses to COVID-19 in the Migration and Asylum área. January-March 2020. Available online: https:/ / ec.europa.eu/home-affairs/sites/ default/files/00_eu_30_emn_bulletin_annex_covid_19.pdf (accessed on 20 April 2021).

European Migration Network (EMN). 2021. Inform \#5-Impact of Covid-19 Pandemic on Voluntary and Forced Return Procedures and Policy Responses. Available online: https://ec.europa.eu/home-affairs/sites/default/files/docs/pages/00_eu_inform5 _return_en.pdf (accessed on 20 April 2021).

Erfani, Parsa, Nishant Uppal, Caroline Lee, Ranit Mishori, and Katherine Peeler. 2021. COVID-19 Testing and Cases in Immigration Detention Centers, April-August 2020. JAMA 325: 182-84. [CrossRef] [PubMed]

Esposito, Francesca, Emilio Caja, and Giacomo Mattiello. 2020. “No one is Looking at Us Anymore." Migrant Detention and Covid-19 in Italy. Border Criminologies. Available online: www.law.ox.ac.uk/sites/files/oxlaw/no_one_is_looking_at_us_anymore_1.pdf (accessed on 4 May 2021).

Europa Press. 2020a. Interior abre la Puerta Liberar a Internos en CIE tras Analizar 'caso por caso' Posibilidades de Retorno. Europa Press. Available online: www.europapress.es/epsocial/migracion/noticia-interior-abre-puerta-liberar-internos-cie-analizarcaso-caso-posibilidades-retorno-20200319192419.html (accessed on 13 April 2021).

Europa Press. 2020b. Los dos centros de internamiento de extranjeros de Canarias ya están vacíos. ElDiario. Available online: www. eldiario.es/canariasahora/365-dias-de-migraciones/centros-internamiento-extranjeros-canarias-vacios_132_1211080.html (accessed on 13 April 2021).

European Commission. 2017. Commission Recommendation of 7 March 2017 on Making Returns More Effective When Implementing the Directive 2008/115/EC of the European Parliament and of the Council. C(2017) 1600 Final. Available online: https:/ / ec.europa.eu/home-affairs/sites/default/files/what-we-do/policies/european-agenda-migration/20170302 _commission_recommendation_on_making_returns_more_effective_en.pdf (accessed on 19 April 2021).

European Commission. 2020a. Communication from the Commission. Covid-19: Guidance on the Implementation of Relevant EU Provisions in the Area of Asylum and Return Procedures and on Resettlement. C(2020) 2516 Final. Available online: https:/ /ec. europa.eu/info/sites/info/files/guidance-implementation-eu-provisions-asylum-retur-procedures-resettlement.pdf (accessed on 20 April 2021).

European Commission. 2020b. Communication from the Commission to the European Parliament, the Council, the European Economic and Social Committee and the Committee of the Regions on a New Pact on Migration and Asylum. COM(2020) 609 Final. Available online: https:/ / eur-lex.europa.eu/resource.html?uri=cellar:85ff8b4f-ff13-11ea-b44f-01aa75ed71a1.0002.02/DOC_3\&format=PDF (accessed on 19 April 2021).

European Commission. 2021. Member States' Notifications of the Temporary Reintroduction of Border Control at Internal Borders Pursuant to Article 25 and 28 et seq. of the Schengen Borders Code. Available online: https:/ / ec.europa.eu/home-affairs/sites/ default/files/what-we-do/policies/borders-and-visas/schengen/reintroduction-border-control/docs/ms_notifications_-_ reintroduction_of_border_control.pdf (accessed on 6 April 2021).

Expresso. 2020. Carta aberta. Covid-19 e os Centros de Detenção em Portugal: 41 associações e mais de 100 cidadãos pedem libertação dos Migrantes. Expresso. Available online: https:/ / expresso.pt/opiniao/2020-04-09-Carta-aberta.-Covid-19-e-os-Centros-deDetencao-em-Portugal-41-associacoes-e-mais-de-100-cidadaos-pedem-libertacao-dos-migrantes (accessed on 12 April 2021).

FARR. 2020. Stoppa Utvisningarna av våra Medmänniskor Omedelbart! Available online: www.mynewsdesk.com/se/farr/ pressreleases / stoppa-utvisningarna-av-vaara-medmaenniskor-omedelbart-2982462 (accessed on 12 April 2021).

Fernández, Soraya. 2021. Interior reabre el Desvencijado CIE de Algeciras tras Gastar más de un millón en reformas. ABC. Available online: https: / / sevilla.abc.es/andalucia / cadiz/sevi-interior-reabre-desvencijado-algeciras-tras-gastar-mas-millon-reformas202101230944_noticia.html (accessed on 13 April 2021).

Fernández-Bessa, Cristina. 2021. Los Centros de Internamiento de Extranjeros: Una Introducción Desde las Ciencias Penales. Madrid: Iustel. 
Fernández Bessa, Cristina, and José Ángel Brandariz. 2018. 'Profiles' of Deportability: Analyzing Spanish Migration Control Policies from a Neocolonial Perspective. In The Palgrave Handbook of Criminology and the Global South. Edited by Kerry Carrington, Russell Hogg, John Scott and Máximo Sozzo. London: Palgrave, pp. 775-95.

Fialho, Christina, and Nacho Hernández Moreno. 2020. In the Age of COVID, Spain Offers the World a Pathway to Detention Abolition. Immprint. July 7. Available online: https://imm-print.com/in-the-age-of-covid-spain-offers-the-world-a-pathway-to-detentionabolition/ (accessed on 31 May 2021).

Fundamental Rights Agency (FRA). 2020a. Migration: Key Fundamental Rights Concerns-Quarterly Bulletin 3-2020. Available online: https: / fra.europa.eu/en/publication/2020/migration-key-fundamental-rights-concerns-quarterly-bulletin-3-2020 (accessed on 21 April 2021).

Fundamental Rights Agency (FRA). 2020b. Migration: Key Fundamental Rights Concerns—Quarterly Bulletin 4-2020. Available online: https:/ / fra.europa.eu/en/publication/2020/migration-key-fundamental-rights-concerns-quarterly-bulletin-4-2020 (accessed on 21 April 2021).

García Hernández, César Cuauhtémoc. 2014. Immigration Detention as Punishment. UCLA Law Review 61: $1346-414$.

García Hernández, César Cuauhtémoc. 2017. Abolishing Immigration Prisons. Boston University Law Review 97: 245 -300.

Global Detention Project (GDP). 2020. Country Report: Immigration Detention in Belgium: Covid-19 Puts the Brakes on an Expanding Detention System. Available online: www.globaldetentionproject.org/immigration-detention-belgium-2020 (accessed on 21 April 2021).

Genschel, Philipp, and Markus Jachtenfuchs. 2021. Postfunctionalism reversed: Solidarity and rebordering during the COVID-19 pandemic. Journal of European Public Policy 28: 350-69. [CrossRef]

Gibney, Matthew. 2008. Asylum and the Expansion of Deportation in the United Kingdom. Government and Opposition 43: $146-67$. [CrossRef]

Gobierno de España. 2020. El Ministerio de Inclusión alcanzará las 7.000 plazas propias de acogida en siete nuevos espacios en Canarias. In Gabinete de Comunicación. Ministerio de Inclusión, Seguridad social y Migraciones; November 20. Available online: https:/ / prensa.inclusion.gob.es/WebPrensaInclusion/noticias/ministro/detalle/3935 (accessed on 2 June 2021).

Hafezi, Parisa. 2020. Iran Temporarily Frees 85,000 from Jail Including Political Prisoners. Reuters. March 17. Available online: www.reuters.com/article/us-health-coronavirus-iran-prisoners-idUSKBN21410M (accessed on 19 April 2021).

Hall, Ben, Guy Chazan, Daniel Dombey, Sam Fleming, Davide Ghiglione, Miles Johnson, Sam Jones, and Victor Mallet. 2020. How Coronavirus Exposed Europe's Weaknesses. Financial Times. Available online: www.ft.com/content/efdadd97-aef5-47f1-91defe02c41a470a (accessed on 16 April 2021).

Harger, Rachel. 2020. Immigration Detention and the Politics of COVID-19. Red Pepper. Available online: www.redpepper.org.uk/ immigration-detention-and-the-politics-of-covid-19/ (accessed on 12 April 2021).

Hasselberg, Ines. 2016. Enduring Uncertainty: Deportation, Punishment and Everyday Life. New York: Berghahn.

Hawks, Laura, Steffie Woolhandler, and Danny McCormick. 2020. COVID-19 in Prisons and Jails in the United States. JAMA Internal Medicine 180: 1041-42. [CrossRef] [PubMed]

Home Office. 2020. Statistics Relating to COVID-19 and the Immigration System, May 2020. Available online: https: / / assets.publishing.service.gov.uk/government/uploads/system/uploads/attachment_data/file/887808/statistics-relatingto-covid-19-and-the-immigration-system-may-2020.pdf (accessed on 12 April 2021).

Home Office. 2021. Guidance for Immigration Removal Centres (IRCs), Residential Short-Term Holding Facilities (RSTHFs) and Escorts during the COVID-19 Pandemic: Version 5.0. Available online: https://assets.publishing.service.gov.uk/government/uploads/ system/uploads/attachment_data/file/957918/detention-and-escorting-services-guidance-during-covid-19-v5.0.pdf (accessed on 12 April 2021).

Hooks, Gregory, and Bob Libel. 2020. Hotbeds of Infection: How ICE Detention Contributed to the Spread of COVID-19 in the United States. Geneva: Global Detention Network, Available online: www.detentionwatchnetwork.org/sites/default/files/reports/DWN_ Hotbeds\%20of\%20Infection_2020_FOR\%20WEB.pdf (accessed on 19 April 2020).

Hooks, Gregory, and Wendy Sawyer. 2020. Mass Incarceration, COVID-19, and Community Spread. Northampton: Prison Policy Initiative, Available online: www.prisonpolicy.org/reports/covidspread.html (accessed on 8 April 2021).

Human Rights Watch (HRW). 2020. Spain: Respect Rights of People Arriving by Sea to Canary Islands. Ensure Adequate Reception Conditions, Accedd to Information and Asylum. Available online: www.hrw.org/news/2020/11/11/spain-respect-rightspeople-arriving-sea-canary-islands (accessed on 2 June 2021).

International Commission of Jurists (ICJ). 2020. The Impact of COVID-19 Related Measures on Human Rights of Migrants and Refugees in the EU: Briefing Paper. Available online: www.icj.org/wp-content/uploads/2020/06/Covid19-impact-migrans-Europe-Brief2020-ENG.pdf (accessed on 21 April 2021).

InfoMigrants. 2020. Deportations from Germany Halved During Pandemic. InfoMigrants. Available online: www.infomigrants.net/en/ post/25997/deportations-from-germany-halved-during-pandemic (accessed on 19 April 2021).

Inquest. 2020. Powerful Coalition of Organisations Call on Government to Immediately Reduce Number of People in Detention Settings. Available online: www.inquest.org.uk/covid-19-letter (accessed on 12 April 2021).

Ironmonger, Jon. 2020. Coronavirus: UK Detention Centres 'Emptied in Weeks'. BBC. Available online: www.bbc.com/news/uk-5256 00932020 (accessed on 12 April 2021). 
Jesuit Refugee Service (JRS). 2021. Covid-19 and Immigration Detention: Lessons (Not) Learned. Available online: https:/ /jrseurope. org/en/resource/covid-19-and-immigration-detention-lessons-not-learned/ (accessed on 21 April 2021).

Kassie, Emily, and Barbara Marcolini. 2020. How ICE Exported the Coronavirus. The Marshall Project. Available online: www.themarshallproject.org /2020/07/10/how-ice-exported-the-coronavirus?utm_medium=social\&utm_campaign=sharetools\&utm_source=twitter\&utm_content=post-top (accessed on 14 April 2021).

Kerwin, Donald. 2020. Immigration Detention and Covid-19: How a Pandemic Exploited and Spread through the US Immigration Detention System. New York: Center for Migration Studies, Available online: https://cmsny.org/wp-content/uploads/2020/08/CMSDetention-COVID-Report-08-12-2020.pdf (accessed on 19 April 2021).

Kluth, Andreas. 2021. For the EU to Survive, It Can't Keep Failing. Bloomberg. Available online: www.bloomberg.com/opinion/ articles/2021-03-04/the-european-union-is-failing-to-protect-its-own-citizens (accessed on 16 April 2021).

Knews. 2020a. NGOs Raise Alarm over Inhumane Conditions at Overcrowded Migrant Camp. Knews. Available online: https:/ /knews. kathimerini.com.cy/en/news/ngos-raise-alarm-over-inhumane-conditions-at-overcrowded-migrant-detention-camp (accessed on 9 April 2021).

Knews. 2020b. Mass Deportations Underway in Cyprus. Knews. Available online: https://knews.kathimerini.com.cy/en/news/massdeportations-underway-in-cyprus (accessed on 19 April 2021).

Knews. 2021. Officials Weigh in on Pournara Brawl. Knews. Available online: https://knews.kathimerini.com.cy/en/news/officialsweigh-in-on-pournara-brawl (accessed on 19 April 2021).

Kucukgocmen, Ali. 2020. Turkish Parliament Passes Bill to Free Thousands from Prison Amid Coronavirus. Toronto: Reuters, Available online: www.reuters.com/article/us-turkey-security-prisoners-idUSKCN21V241 (accessed on 19 April 2021).

La Cimade. 2020. Enfermement en Rétention Malgré la Situation Sanitaire et des Frontières Fermées aux Expulsions. Available online: www.lacimade.org/enfermement-en-retention-malgre-la-situation-sanitaire-et-des-frontieres-fermees-aux-expulsions/ (accessed on 9 April 2020).

Lasciateentrare. 2020. Associazioni e avvocati di tutta Italia scrivono al Ministro, alle Prefetture e ai Questori. Lasciateentrare. Available online: www.lasciatecientrare.it/emergenza-coronavirus-bloccare-gli-ingressi-nei-cpr-e-procedere-alla-progressiva-chiusuradei-centri/ (accessed on 9 April 2020).

Lecadre, Renaud. 2020. Coronavirus: Le Conseil d'Etat refuse la fermeture des centres de retention. Libération. Available online: www. liberation.fr/france/2020/03/27/coronavirus-le-conseil-d-etat-refuse-la-fermeture-des-centres-de-retention_1783367/ (accessed on 9 April 2020).

Leerkes, Arjen, and Dennis Broeders. 2010. A case of mixed motives? Formal and informal functions of administrative immigration detention. The British Journal of Criminology 50: 830-50. [CrossRef]

Leerkes, Arjen, and Mieke Kox. 2017. Pressured into a Preference to Leave? A Study of the "Specific" Deterrent Effects and Perceived Legitimacy of Immigration Detention. Law \& Society Review 51: 895-929.

Lindberg, Annika, Anna Lundberg, Sofia Häyhtiö, and Elisabet Rundqvist. 2020. Detained and Disregarded: How COVID-19 Has Affected Detained and Deportable Migrants in Sweden. Border Criminologies. Available online: www.law.ox.ac.uk/researchsubject-groups/centre-criminology/centreborder-criminologies/blog/2020/07/detained-and (accessed on 12 April 2021).

Lopez, William, Nolan Kline, Alana LeBrón, Nicole Novak, María Elena De Trinidad Young, Gregg Gonsalves, Ranit Mishori, Basil Safi, and Ian Kysel. 2021. Preventing the Spread of COVID-19 in Immigration Detention Centers Requires the Release of Detainees. American Journal of Public Health 111: 110-15. [CrossRef]

López-Riba, José María. 2020. La gestión policial de la crisis sanitaria. Ctxt. Available online: https://ctxt.es/es/20200401/Politica/31 731/Jose-Maria-Lopez-Riba-policia-coronavirus-confinamiento-estado-alarma.htm (accessed on 14 April 2021).

Lopez-Sala, Ana. 2021. Luchando por sus derechos en tiempos de Covid-19. Resistencias y reclamaciones de regularización de los migrantes Sinpapeles en España. REMHU, Revista Interdisciplinar da Mobilidade Humana 29: 83-96. [CrossRef]

Loran, Charlie. 2020. Riots at the CETI Centre in Melilla Come to an End, But How Long for? EuroWeekly News. Available online: www.euroweeklynews.com/2020/08/27/riots-at-the-ceti-centre-in-melilla-come-to-an-end-but-how-long-for/ (accessed on 19 April 2021).

MacGregor, Marion. 2021. New Migrant Camps in the Canary Islands. InfoMigrants. Available online: www.infomigrants.net/en/ post/29909/spain-new-migrant-camps-in-the-canary-islands (accessed on 15 April 2021).

Macmadu, Alexandria, Justin Berk, Eliana Kaplowitz, Marquisele Mercedes, Josiah Rich, and Lauren Brinkley-Rubinstein. 2020. COVID-19 and mass incarceration: A call for urgent action. The Lancet Public Health 5: E71-E72. [CrossRef]

Majcher, Izabella, Michael Flynn, and Mariette Grange. 2020. Introduction: Harmonising, Institutionalising, Normalising: How the "Crisis" Became an Opportunity for Expanding Immigration Detention Regimes. In Immigration Detention in the European Union: In the Shadow of the 'Crisis'. Edited by Izabella Majcher, Michael Flynn and Mariette Grange. Cham: Springer, pp. 1-13.

Majkowska-Tomkin, Magda. 2020. Countries Are Suspending Immigration Detention Due to Coronavirus. Let's Keep It That Way. Euronews. Available online: www.euronews.com/2020/04/29/countries-suspending-immigration-detention-due-tocoronavirus-let-s-keep-it-that-way-view (accessed on 8 April 2021).

Martín, María. 2020. Los Centros de Internamiento de Extranjeros se vacían por primera vez en tres décadas. El País. Available online: https: / / elpais.com/espana/2020-05-06/se-vacian-los-centros-de-internamiento-de-extranjeros-por-primera-vez-entres-decadas.html (accessed on 12 April 2021). 
Martín, María. 2021. Tension Spreads Through Migrant Shelters in Spain's Canary Islands. El País. Available online: https:/ /english. elpais.com/spanish_news/2021-02-08/tension-spreads-through-migrant-shelters-in-spains-canary-islands.html (accessed on 15 April 2021).

Martínez, Daniel, Jeremy Slack, and Ricardo Martínez-Schuldt. 2018. The Rise of Mass Deportation in the United States. In The Handbook of Race, Ethnicity, Crime, and Justice. Edited by Ramiro Martínez Jr., Meghan Hollis and Jacob Stowell. Hoboken: Willey Blackwell, pp. 173-201.

Mitsilegas, Valsamis. 2015. The Criminalisation of Migration in Europe: Challenges for Human Rights and the Rule of Law. New York: Springer.

Moffette, David. 2018. Governing Irregular Migration: Bordering Culture, Labour, and Security in Spain. Vancouver: UBC Press.

Mucchielli, Julien. 2020. Les centres de rétention se vident, l'administration persiste. Dalloz actualité. Available online: www.dallozactualite.fr/flash/centres-de-retention-se-vident-1-administration-persiste\#.YHB0eT9pqU1 (accessed on 9 April 2021).

Muñoz, Lucía, and Jairo Vargas. 2020. Interior reabre de inmediato y en plena segunda ola los CIE cerrados por la pandemia. Público. Available online: www.publico.es/sociedad/reapertura-cie-interior-reabre-inmediato-plena-segunda-ola-cie-cerradospandemia.html (accessed on 13 April 2021).

NOS. 2020. Vreemdelingen vrijgelaten uit detentie vanwege coronacrisis. NOS. Available online: https://nos.nl/artikel/2328839vreemdelingen-vrijgelaten-uit-detentie-vanwege-coronacrisis.html (accessed on 12 April 2021).

Observatoire de l'enfermement des étrangers (OEE). 2020. Face à la crise sanitaire, l'enfermement administratif des personnes étrangères doit immédiatement cesser. Available online: https://observatoireenfermement.blogspot.com/p/communiques-de-presse.html (accessed on 9 April 2021).

Orejudo, Patricia. 2020. Los centros de internamiento de extranjeros ante la situación del Covid-19. Otrosí. Available online: www.otrosi.net/analisis/los-centros-internamiento-extranjeros-ante-la-situacion-del-covid-19 (accessed on 14 April 2021).

Piser, Karina. 2020. The End of Immigration Detention Doesn't Mean the End of Fortress Europe. Foreign Policy. Available online: https: / f foreignpolicy.com/2020/07/31/coronavirus-asylum-end-immigration-detention-spain-france-end-of-fortresseurope/ (accessed on 16 April 2021).

Refugee Rights Europe. 2020. The Invisible Islands: Covid-19 Restrictions and the Future of Detention on Kos and Leros. Available online: https:/ / refugee-rights.eu/wp-content/uploads/2020/05/RRE_TheInvisibleIslands.pdf (accessed on 9 April 2021).

Roman, Emanuela. 2020. Rethinking Immigration Detention During and After Covid-19: Insights from Italy. Border Criminologies. Available online: www.law.ox.ac.uk/research-subject-groups/centre-criminology/centreborder-criminologies/blog/2020/06/ rethinking (accessed on 3 April 2021).

Rosenberger, Sieglinde, and Carla Küffner. 2016. After the Deportation Gap: Non-Removed Persons and their Pathways to Social Rights. In Migration and Integration: New Models for Mobility and Coexistence. Edited by Roland Hsu and Cristoph Reinprecht. Wien: Vienna University Press, pp. 137-50.

Sainz, Pablo 'Pampa'. 2020. El Defensor del Pueblo confirma la liberación de internas de los CIE. El Salto. Available online: www. elsaltodiario.com/coronavirus/defensoria-del-pueblo-confirma-la-liberacion-de-internas-del-cie (accessed on 13 April 2021).

Saiz, Eva. 2020. Los centros de extranjeros se han vaciado por la pandemia y no ha habido una hecatombe. El País. Available online: https:/ / elpais.com/espana /2020-06-18/los-centros-de-extranjeros-se-han-vaciado-por-la-pandemia-y-no-ha-habidouna-hecatombe.html (accessed on 18 April 2021).

Sánchez, María. 2020a. Vuelven el sufrimiento y la incertidumbre con la reapertura de los CIE en plena pandemia. Cuarto Poder. Available online: www.cuartopoder.es/derechos-sociales/2020/10/24/vuelven-el-sufrimiento-y-la-incertidumbre-con-la-reaperturade-los-cie-en-plena-pandemia / (accessed on 13 April 2021).

Sánchez, María. 2020b. El año en el que se cerraron los CIE (y se volvieron a abrir). Cuarto Poder. Available online: www.cuartopoder. es/sociedad/2020/12/28/el-ano-en-el-que-se-cerraron-los-cie-y-se-volvieron-a-abrir/ (accessed on 14 April 2021).

Shah, Silky. 2021. The Immigrant Justice Movement Should Embrace Abolition. The Forge. March 4. Available online: https: / / forgeorganizing.org/article/immigrant-justice-movement-should-embrace-abolition (accessed on 31 May 2021).

Sharma, Damini, Weihua Li, Denise Lavoie, and Claudia Lauer. 2020. Prison Populations Drop by 100,000 During Pandemic. The Marshall Project. Available online: www.themarshallproject.org/2020/07/16/prison-populations-drop-by-100-000-duringpandemic (accessed on 8 April 2021).

Shenker, Jack. 2021. Locked in Barracks with Covid Running Rampant: Is This Any Way to Treat Asylum Seekers? The Guardian. Available online: www.theguardian.com/commentisfree/2021/jan/27/locked-covid-asylum-seekers-napier-barracks-kent (accessed on 19 April 2021).

Solidarité Sans Frontières (SSF). 2020. Coronavirus: Des mesures de protection pour tout le monde. Available online: www.sosf.ch/fr/ sujets/asile/informations-articles/appel-aux-autorites.html (accessed on 12 April 2020).

Stuber, Lea, and Christian Zeier. 2021. Neue Vorwürfe an Betreiberin nach massivem Corona-Ausbruch. Berner Zeitung. Available online: www.bernerzeitung.ch/neue-vorwuerfe-an-betreiberin-nach-massivem-corona-ausbruch-622541895066?fbclid=IwAR3 QY1FX-vbXkdHSDst-S0RFqibTV345zjYWIKYD9814iekF42Pmf8HDC0A (accessed on 18 April 2021).

Taylor, Diane. 2020a. Coronavirus: Call to Release UK Immigration Centre Detainees. The Guardian. Available online: www.theguardian. com/world/2020/mar/14/coronavirus-call-to-release-uk-immigration-centre-detainees (accessed on 12 April 2020). 
Taylor, Diane. 2020b. Home Office Accused of Pressuring Judiciary over Immigration Decisions. The Guardian. Available online: www. theguardian.com/politics/2020/may/06/home-office-accused-of-pressuring-judiciary-over-immigration-decisions (accessed on 12 April 2021).

Tosh, Sarah, Ulla Berg, and Kenneth Sebastian León. 2021. Migrant Detention and COVID-19: Pandemic Responses in Four New Jersey Detention Centers. Journal on Migration and Human Security 9: 44-62. [CrossRef]

Trandum Supervisory Board. 2021. Tilsynsrådet for Politiets utlendingsinternat, Trandum: Årsmelding 2020. Available online: www. regjeringen.no/contentassets/e19229021ca74bee9f678d1b52b70f4b/arsmelding-trandum-2020.pdf (accessed on 12 April 2021).

Tribune de Genève. 2020. Des détenus libérés de détention administrative. Tribune de Genève. Available online: www.tdg.ch/suisse/ detenus-liberes-detention-administrative/story/13892640 (accessed on 12 April 2021).

Turnbull, Sarah. 2017. Immigration Detention and Punishment. Oxford Research Encyclopedia. Criminology and Criminal Justice, 1-24. [CrossRef]

United Nations Working Group on Alternatives to Immigration Detention (UNWGATD). 2020. COVID-19 \& Immigration Detention: What Can Governments and Other Stakeholders Do? Available online: https://migrationnetwork.un.org/sites/default/files/ docs/un_network_on_migration_wg_atd_policy_brief_covid-19_and_immigration_detention_0.pdf (accessed on 20 April 2021).

Vargas, Natalia. 2020. El juez de control del CIE de Barranco Seco ordena la libertad de los internos por razones de salud pública. El Diario. Available online: www.eldiario.es/canariasahora/365-dias-de-migraciones/cie-barranco-seco-libertad-internos_132_ 1220191.html (accessed on 13 April 2021).

Vargas, Natalia. 2021. El brote de COVID-19 en Hoya Fría afecta a 21 personas y vuelve a evidenciar las carencias del CIE. El Diario. February 3. Available online: www.eldiario.es/canariasahora/migraciones/cie-hoya-fria-brote-tenerife-covid_1_7191231.html (accessed on 18 April 2021).

Vaughan-Williams, Nick. 2015. Europe's Border Crisis: Biopolitical Security and Beyond. Oxford: Oxford University Press.

Weber, Leanne. 2020. Could a Pandemic Kickstart the Re-Bordering of the World? Border Criminologies. Available online: www.law. ox.ac.uk/research-subject-groups/centre-criminology/centreborder-criminologies/blog/2020/07/could-pandemic (accessed on 3 April 2021).

WHO. 2020. UNODC, WHO, UNAIDS and OHCHR Joint Statement on COVID-19 in Prisons and Other Closed Settings. Available online: www.who.int/news/item/13-05-2020-unodc-who-unaids-and-ohchr-joint-statement-on-covid-19-in-prisons-and-otherclosed-settings (accessed on 16 April 2021).

WHO Europe. 2020a. Preparedness, Prevention and Control of COVID-19 in Prisons and Other Places of Detention: Interim Guidance. 15 March 2020. Available online: https:/ / apps.who.int/iris/bitstream/handle/10665/336525/WHO-EURO-2020-1405-41155-55 954-eng.pdf?sequence=1\&isAllowed=y (accessed on 8 April 2021).

WHO Europe. 2020b. Pandemic Fatigue: Reinvigorating the Public to Prevent COVID-19: Policy Considerations for Member States in the WHO European Region. Available online: https:/ / apps.who.int/iris/bitstream/handle/10665/335820/WHO-EURO-2020-1 160-40906-55390-eng.pdf?sequence=3\&isAllowed=y (accessed on 18 April 2021).

Widra, Emily. 2021. How much have COVID-19 releases changed prison and jail populations? Prison Policy Initiative. Available online: www.prisonpolicy.org/blog/2021/02/03/january-population-update/ (accessed on 8 April 2021).

Wille, Christian, and Rebekka Kanesu, eds. 2020. Bordering in Pandemic Times: Insights into the COVID-19 Lockdown. Luxembourg and Trier: UniGR-Center for Border Studies, Available online: https:/ / ubt.opus.hbz-nrw.de/opus45-ubtr/frontdoor/deliver/index/ docId/1428/file/UniGR-CBS_Borders+in+Perspective_thematic+issue_Vol.+4.pdf (accessed on 16 April 2021).

Wonders, Nancy. 2017. Sitting on the fence-Spain's delicate balance: Bordering, multiscalar challenges, and crimmigration. European Journal of Criminology 14: 7-26. [CrossRef]

Ybarra, Megan. 2021. Site Fight! Towards the abolition of immigrant detention on Tacoma's Tar Pits (and everywhere else). Antipode: A Radical Journal of Geography 53: 36-55. [CrossRef]

Zedner, Lucia. 2016. Penal subversions: When is a punishment not punishment, who decides and on what grounds? Theoretical Criminology 20: 3-20. [CrossRef] 